\title{
Homicide, fragile $X$ syndrome, and mental retardation
}

Rev Bras Psiquiatr. 2013;35:443-444

doi:10.1590/1516-4446-2013-1137

Persons with mental retardation represent 1 to $2 \%$ of the worldwide population. Due to their suggestive behavior and ingenuousness, these persons tend to be vulnerable to violence in all its forms. ${ }^{1}$ Nevertheless, difficulties concerning impulse control and lack of judgment contribute to disruptive and maladaptive behaviors in some of them. These misbehaviors may include sexual violence, thefts, pyromania, and homicidal attacks. Comorbid substance abuse is common in this population and increases the risk of these misconducts. Within this context, mentally retarded individuals account for $23.7 \%$ of the population undergoing forensic mental health assessment (FMHA) for evaluation of criminal responsibility at Instituto Psiquiátrico Forense Maurício Cardoso in Porto Alegre, Brazil. ${ }^{2}$

Fragile $X$ syndrome is the main inherited cause of mental retardation worldwide. It is an X-linked neurodevelopmental disorder that affects around 1 in 2,500 individuals. It is caused by mutations in the FMR1 gene, which involve an unstable trinucleotide repeat expansion of the cytosine-guanine-guanine (CGG) codon. ${ }^{3}$ Clinically, fragile $X$ syndrome is characterized by a wide spectrum of medical, psychiatric and behavioral problems. The most frequent behavioral manifestations are social avoidance, multiple symptoms of anxiety, impulsivity, aggressiveness, and alcohol abuse., ${ }^{3,4}$ Disruptive behaviors often require psychiatric treatment, ${ }^{5}$ and it is possible that a significant number of patients with the syndrome may be incarcerated without a diagnosis.

The patient was a 22-year-old single white male, with no formal education, referred to our service for FMHA after being accused of homicide. Shortly after birth, the patient had exhibited developmental delay and seizures, which lasted until age 3 years. In childhood, he used to wander and start fires deliberately. At age 13 , the fragile $X$ syndrome was diagnosed. The patient attended a center for special needs for about 1 year at age 15. Until the age of 19, he made regular use of carbamazepine and irregular use of risperidone. He was eventually lost to medical follow-up and began to make increasing use of alcohol and marijuana. According to his mother, he had episodes of irritability and low frustration tolerance, especially when intoxicated. He continued to increase his intake of psychoactive substances, culminating in a severe episode of outwardly directed aggression, wherein he assaulted an acquaintance with several blows from a knife while under the influence of narcotics. He reported that, about 20 days before $\mathrm{FMHA}$, he again became involved in a knife attack while among a group of alcoholics. There were no reports of other psychiatric and/or genetic diseases in the family. A psychodiagnostic examination conducted during FMHA confirmed moderate mental retardation (IQ 40).

This case highlights how genetic syndromes may be associated with potential for neurological and psychiatric disturbances, with possible behavioral symptoms, and the importance of accurate diagnosis and adequate treatment of this population, as criminal attitudes have been rarely reported. It is also intended as a warning of how comorbid alcohol abuse and lack of medical assistance can contribute to violent and, eventually, criminal outcomes. The study of vulnerable populations can improve our understanding of their functioning, 
limitations, and behaviors, and can provide inputs to propose better, more adequate political actions of public health, with a view to preventing potential legal consequences.

Lisieux Elaine de Borba Telles, ${ }^{1}$ Pedro Henrique Iserhard Zoratto, ${ }^{1}$ Vivian Peres Day, ${ }^{1}$

Rafael Fabiano Machado Rosa ${ }^{2,3}$

${ }^{1}$ Instituto Psiquiátrico Forense Maurício Cardoso, Porto Alegre, RS, Brazil. ${ }^{2}$ Department of Clinical Genetics, Universidade Federal de Ciências da Saúde de Porto Alegre (UFCSPA), and Complexo Hospitalar Santa Casa de Porto Alegre, Porto Alegre, RS, Brazil.

${ }^{3}$ Department of Clinical Genetics, Hospital Materno-Infantil Presidente Vargas (HMIPV), Porto Alegre, RS, Brazil

Submitted Apr 05 2013, accepted May 072013.

\section{Disclosure}

The authors report no conflicts of interest.

\section{References}

1 Abdalla-Filho E, Ribeiro HL. Retardo mental. In: Taborda JG, Abdalla-Filho E, Chalub Miguel, editors. Psiquiatria forense. Porto Alegre: Artmed; 2012. p. 450-65.

2 Telles LEB. Perícias de responsabilidade penal realizadas no Instituto Psiquiátrico Forense. Multijuris: Primeiro Grau em Ação. 2007;2:44-9.

3 Gallagher A, Hallahan B. Fragile X-associated disorders: a clinical overview. J Neurol. 2012;259:401-13.

4 Tranfaglia MR. The psychiatric presentation of fragile $x$ : evolution of the diagnosis and treatment of the psychiatric comorbidities of fragile X syndrome. Dev Neurosci. 2011;33:337-48.

5 Richard-Devantoy S, Olie JP, Gourevitch R. [Risk of homicide and major mental disorders: a critical review]. Encephale. 2009;35:521-30. 